\title{
Pests of safflower (Carthamus tinctorious l.) and their natural enemies in Gachsara, Iran.
}

\begin{abstract}
The safflower fly, Acanthiophilus helianthi Rossi, 1794 (Diptera: Tephritidae) is one of the most important pests of safflower in Iran. Losses caused by larval feeding leads to disrupted plant activities, reduction in flower buds, and, ultimately, to decreased quality and quantity of crop. An investigation was made from March 2008 to August 2009 in Gachsaran and Yasooj to record the pest status of safflower and their natural enemies. A total of twenty arthropods were recorded as pests of safflower. Out of 25 farms surveyed, only seven had the incidence of pest attack. Among the pests, Safflower fly and Silver - Y- moth were found to cause considerable damage to the safflower plants, while others were not at economic levels. Among the natural enemies, parasitoids like Bracon hebetor, Bracon luteator, Colotrechnus viridis, Antistrophoplex conthurnatus, Microdontomenus annulatus, Ormyrus orientalis, Eurytoma acroptilae, Pronotalia carlinarum, Pteromalus sp. and Isocolus tinctorious were found to be associated with the pests of safflower.
\end{abstract}

Keyword: Safflower; Pests; Natural enemies. 